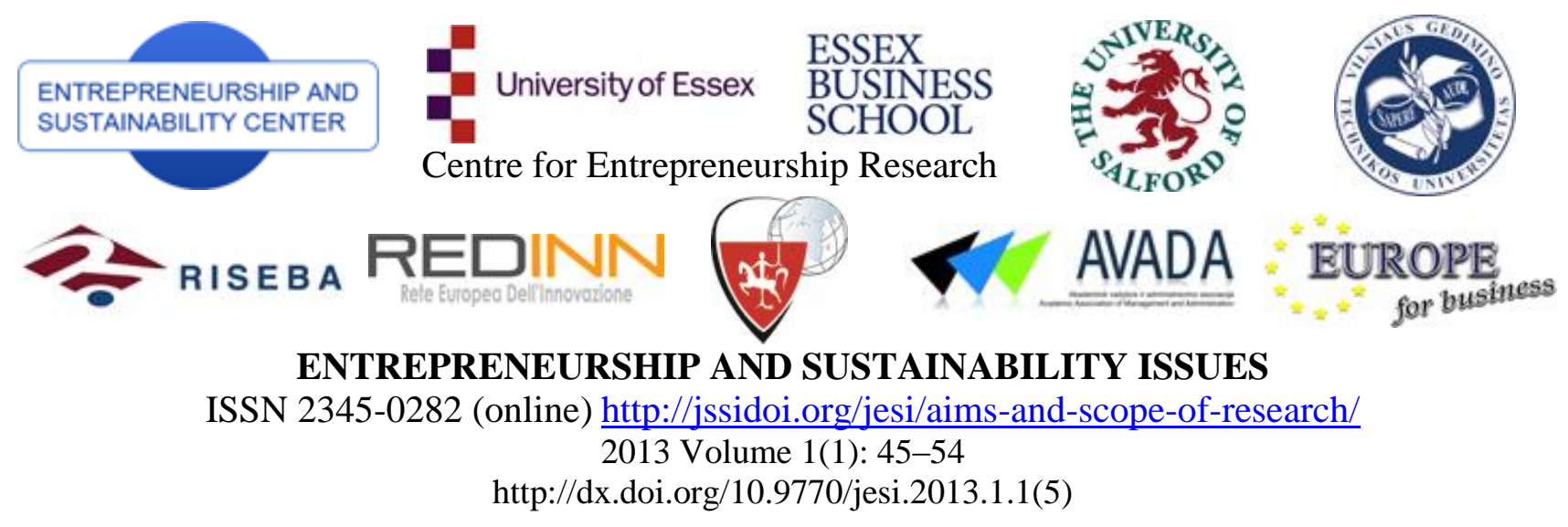

\title{
SOCIAL ENTERPRISES AS A TOOL OF SOCIAL AND ECONOMIC POLICY. LITHUANIAN CASE
}

\author{
Julija Moskvina \\ Lithuanian Social Research Centre \\ Goštauto g. 11, LT-01108 Vilnius, Lithuania \\ E-mail: Julija.Moskvina@dsti.lt
}

Received 15 March 2013; accepted 20 June 2013

\begin{abstract}
The social enterprise is a quite new phenomenon which derives from the development of the social economy aiming to combine social, economic and political targets. Nowadays the social economy is considered as effective way to create and manage a human capital with the recognition of the importance of personal and community interests. In the most countries of the European Union the social enterprises are significant element of development of the non-governmental sector. The implementation of the principles of social economy in Lithuania is characterized by certain peculiarities. The creation of the modern, "West-type" social enterprises in Lithuania was highly welcomed in regard to the social and economical changes in society, such as social exclusion of vulnerable groups, growing pressure on the social security system, the need to vitalise local communities, etc. In 2004 the Law on Social Enterprises came in force and more than 100 enterprises were established in the country till now. It worth mention that the businesses aimed to employment of disabled people existed also in soviet period; some of them gained the status of social enterprises later. The concept of social enterprises is still under consideration though. The obstacles to involve other vulnerable groups than disabled are strong. The elaboration of the vision, clarification of the aims and targets of social enterprises as the tool of social and economic development require thorough analysis of the past trends, present conditions, and future developments. Paper aims to identify the main differences between mainstream European concept of social enterprise and the Lithuanian situation in social enterprises. The phenomenon of social enterprises presented in the context of the changing social and employment policy in West and East European countries. The situation in Lithuanian social enterprises is described on the basis of extensive information selected from representatives of social enterprises, the experts, and the institutionalised data. The methods of literature analysis, statistical data analysis, qualitative interview, and content analysis were employed during the research. The paper is prepared under the research project "The impact of labour market policies into employment situation during the different economic cycles" (No. Sin04/2010) that is implemented within the frame of national science program "The social challenges to national security" which is carried out by the Research Council of Lithuania.
\end{abstract}

Keywords: social economy, social enterprises, vulnerable groups.

Reference to this paper should be made as follows: Moskvina, J. 2013. Social enterprises as a tool of social and economic policy, Entrepreneurship and Sustainability Issues 1(1): 45-54.

http://dx.doi.org/10.9770/jesi.2013.1.1(5)

JEL Classification: E24, E60.

\section{Introduction}

The search for the ways to reduce the conflicts between business and human, community, and social interest in contemporary economic world materialised in the form of social enterprises. The social businesses became an opportunity for the vulnerable groups and communities to solve the issues of social integration. In this way social enterprises are positioned between the traditional private and public sectors. The emergence of social enterprises as a part of social economy in Western Europe is linked with the extensive processes of 
social integration of disadvantaged groups. It should be noted that development of social economic units and social enterprises among them in different European countries was quite spontaneous. It was the response to the local socio-economic problems, such as inadequate social services, the high level of social differentiation, and the pressure on social welfare schemes. In order to describe the meaning of social enterprise for social and economic policy it is necessary to define the socio-economic context within which social enterprises are implementing activities aimed for social integration. The key problems that are challenging European social and economic policies are described in the paper. On the basis of literature analysis the common features of European social enterprise sector are described in the paper. The findings research project "The impact of labour market policies on employment situation during the different economic cycles" carried out by the Institute of Labour and Social Research of Lithuanian Social Research Centre are presented here. The evaluation of the social enterprises operating in Lithuania while integrating vulnerable groups into labour market was implemented during the project. The approach of evaluation of national social enterprises has been derived from the findings of foreign authors about the "hybrid" nature of such enterprises (Defourny, Nyssens 2006). The methodology of the evaluation of the practices of social enterprises reflects the notion about its triple nature (social, economic, and social-political) as well as the research- and practice-based opinion that social enterprises must contribute to the sustainable employment of the vulnerable groups and/or to the prevention of their economical inactivity.

\section{Challenges for social and employment policies in Europe}

During the past decades the implementation of European social model that aimed to „offer a high level of social protection, by the importance of the social dialogue and by services of general interest covering activities vital for social cohesion, is today based, beyond the diversity of the Member States' social systems, on a common core of values" (European Council 2000) has become a more challenging task. The economic growth in European Union (EU) was modest and the recent downturn has required additional resources to preserve the accustomed scope of social welfare. Promoting the full integration and participation of disadvantaged groups of people is a key element of EU policies. In view of the demographic challenge of an ageing population that the EU is facing, supporting the disadvantaged by helping them contribute to economic growth is in Europe's interest - it is not just a social, but also an economic issue. During the last decades such a key problems remained unsolved in the field of social integration and employment in Europe: poverty and social exclusion, inactivity and growing pressure on the systems of social welfare.

In 2011, 119.6 million people, or $24.2 \%$ of the population, in the EU27 were at risk of poverty or social exclusion, compared with $23.4 \%$ in 2010 and $23.5 \%$ in 2008. As regards the indicator on low work intensity, $10 \%$ of the population aged 0-59 in the EU27 lived in households where the adults worked less than $20 \%$ of their total work potential during the past year (Eurostat news release 2012).

In the EU as a whole, as well as in all individual Member states, social protection is the most important function of government expenditure. In 2010 social protection spending by government in the EU-27 was equivalent to $19.9 \%$ of GDP. The next most important functions in terms of government expenditure were health and general public services, amounting to $7.5 \%$ and $6.5 \%$ respectively of GDP in the EU-27 in 2010 (Freysson 2012). In general, social benefits, subsidies and capital transfers represent the largest category of government expenditure, equivalent to $27.0 \%$ of EU-27 GDP in 2010. Within this group of spending, the redistribution of income in the form of social benefits and transfers in cash or in kind was the most important at $21.6 \%$ of GDP (Freysson 2012).

Taken together, government expenditure on social protection and on health accounted for $54.2 \%$ of total government spending of EU-27 in 2010. Social protection accounted alone for 39.4\% of the total, or 19.9\% of EU-27 GDP. This function includes spending on sickness and disability, old age, family and children, unemployment, housing in the form of benefits in kind, and social exclusion (Freysson 2012).

Since 2000 the share of the inactive population in the total population of working age 1 has fallen from $31.4 \%$ to $28.9 \%$ in the EU-27. This corresponds to a reduction of 4.6 million inactive persons. The 2009 result confirms the downward trend in the population outside the labour market in spite of the economic crisis. The effects of the crisis are visible nevertheless: the reduction of the inactivity rate in 2009 is the lowest recorded percentage since 2002 , i.e., -0.1 points down on 2008 . The crisis has affected people differently depending on their sex and age. While in 2009 the inactivity rate of women aged 25-64 maintained the downward trend seen in previous years, the inactivity rate among men aged 25-64 rose by 0.2 percentage points. Young adults aged 15-24 are affected even more; this is particularly true for males, who saw their inactivity rate increase by 0.9 percentage points between 2008 and 2009. Persons attaining a low educational level are more likely to be inactive. The likelihood of staying out of the labour market is more than 3 times greater for the 
poorly educated than for highly educated people. (De la Fuente 2010). The other reasons of being inactive are illness or disability, family responsibilities, retirement or the belief that there are no jobs available. The latter is an exceptional reason for inactivity. Labour force participation is indeed much lower for the disabled (Dupre, Karjalainen 2003).

The problem of integration of the different groups of migrants should also be mentioned here. In most Member States the labour market situation for migrants is substantially worse than that of those born in the EU - they tend to have lower employment rates and are often more likely to be unemployed, or are employed in jobs of lower quality or for which they are over-qualified. Recent migrants, in particular women and those from certain regions of origin, face particular difficulties in integrating into the labour market (Employment in Europe 2008).

The recent economic crisis has wiped out much of the steady gain in economic growth and the reduction in levels of unemployment witnessed over the last decade - EU GDP fell by $4.2 \%$ in 2009, industrial production dropped back to the levels of the late 1990s (Employment in Europe 2011). In the wake of the financial and economic crisis the level of unemployment climbed rapidly in the EU-27, increasing by 6.3 million persons between 2008 and 2010 to reach 23.2 million persons (that is close to $10 \%$ of the economically active population) (Employment in Europe 2011). The youth unemployment rate in the EU-27 was more than double the unemployment rate for the whole population throughout the last decade. The longterm unemployment problem should be also mentioned in the context of the economic downturn: $3.8 \%$ of the labour force in the EU-27 in 2010 had been unemployed for more than one year; almost half of these, 1.8\% of the labour force, had been unemployed for more than two years (Eurostat 2012).

Despite moderate signs of economic recovery, European labour markets are still suffering from the negative impact of the economic crisis. The crisis has disproportionately hit those who were already vulnerable and has created new categories of people at risk of poverty. There are also clear signs of increases in the number of people at risk of income poverty, notably child poverty, and social exclusion, with acute health problems and homelessness in the most extreme cases. People with no or limited links to the labour market - such as pensioners or vulnerable people dependent on social benefits, for instance single parents - are also exposed to changes affecting the calculation and eligibility of their source of income (Annual Growth Survey 2011).

According to the latest European Commission forecasts (Index of economic...2010), although the EU economy is now recovering at a faster pace than previously envisaged, it will continue to face headwinds from several directions and, despite apparent signs of stabilisation, the labour-market situation will remain weak (Employment in Europe 2011). Access to employment is regarded as the optimal way out of poverty and social exclusion. However, the last decade has seen the persistence of groups who remain outside or on the margins of the labour market, often facing multiple entry barriers (low skills, care responsibilities, age, migrant background, disability and other discriminatory factors, etc.) (Europe 2020 targets 2012).

To protect vulnerable members of society the further improving the effectiveness of social protection systems and implementing active inclusion strategies encompassing inclusive labour market measures, adequate income support and access to quality services should be implemented. The persistence of structural unemployment, the limitations of traditional active labour market policy measures, and the need for more innovative measures for social inclusion cause a demand for new integrational solutions combining the social and economic activities and values.

\section{Social economy}

The range of existing socio-economic organization is trying to be described with the term "social economy". Social economy covers entities operating and social and economic spheres, as well as their activities and interrelations between the aims, norms, values, mission, rights and responsibilities of public and private sectors. The researchers from International Centre of Research and Information on the Public, Social and Cooperative Economy (The Social Economy... 2012b) derive the term "social economy" from the economics literature of $19^{\text {th }}$ century: "In 1830 the French liberal economist Charles Dunoyer published a Treatise on social economy that advocated a moral approach to economics. Over the 1820-1860 period, a heterogeneous school of thought that can collectively be termed the social economists developed in France. Most of them were influenced by the analyses of T.R. Malthus and S. de Sismondi, regarding both the existence of 'market failures' that can lead to imbalances, and the delimitation of the true subject of economics, which Sismondi considered to be man rather than wealth."

Then during the second half of the 19th century the theme of "social economics" was examined in the works of Stuart Mill and Leon Walras. Mill analysed the advantages and drawbacks of workers' cooperatives in detail, calling for this type of company to be encouraged because of its economic and moral benefits. Like 
Mill, Walras considered that cooperatives can fulfil an important function in solving social conflict by playing a great "economic role, not by doing away with capital but by making the world less capitalist, and a moral role, no less considerable, which consists in introducing democracy into the workings of the production process" (Monzon 1989; The Social Economy...2012b). At the end of the 19th century the principal features of the modern concept of the social economy took shape, inspired by the values of democratic associationism, mutualism and cooperativism (The Social Economy... 2012b). Major components typically include social economy businesses, community development corporations, social enterprises, and mutual aid associations. Public sector nonprofits are considered part of the social economy. Essentially, "the social economy is made up of the voluntary, non-profit and co-operative sectors that are formally independent of the state. Their market activities are means of achieving social development goals that transcend the market per se. Thus defined, the social economy should be logically considered as a third sector" (Browne 1997: 1; Moulaert and Ailenei 2005).

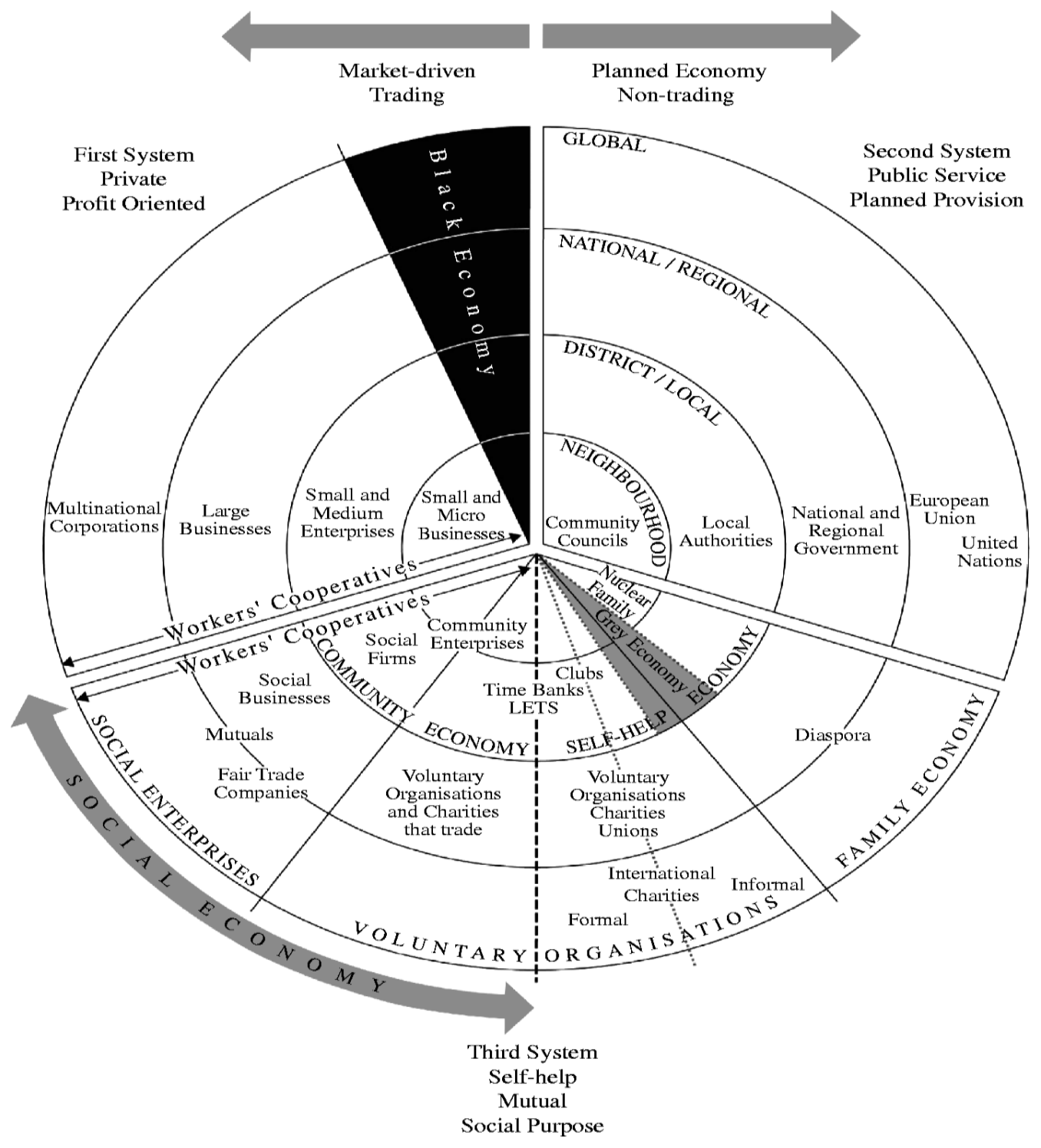

Fig.1. Three Systems of the Economy

Source: Pearce (2003)

Moulaert and Ailenei (2005) come to conclusion that "social economy develops as a permanent stream of inventions of various social mechanisms, mixing market exchange, state intervention, collective civil sector organisation based on social movements driven by solidarity and reciprocity" (Moulaert and Ailenei (2005: 2049). As Pearce (2005) indicates, "we are witnessing a profound change in how we understand our national economies where third sector constitute significant part of the economy. It ranges from - at one end of a long continuum - small, local initiatives such as village halls, local markets, pre-school play-groups run by volunteers but often with some part-time paid work - playing a definite role in local economies, to - at the 
other end - substantial, highly commercial, competitive and successful businesses. And in between are a vast range of enterprises and organisations - community co-ops, social firms creating supported employment, credit unions, fair trade companies, development trusts, community businesses; as well as voluntary and community organisations and charities which increasingly earn much of their income from business and fulfil contracts from the public sector" (Pearce 2005) (See Fig.1.). In the context of European Union policies for promotion of entrepreneurship it is recognised that the enterprises and organizations belonging to social economy has the following characteristics: they contribute to a more efficient market competition and encourage solidarity and cohesion. Their primary purpose is not to obtain a return on capital. They are, by nature, part of a stakeholder economy, whose enterprises are created by and for those with common needs, and accountable to those they are meant to serve. They are run generally in accordance with the principle of solidarity and mutuality and managed by the members on the basis of the rule of "one man, one vote." They are flexible and innovative in meeting social and economic context. They are based on active membership and commitment and very frequently on voluntary participation (European Commission 2012).

Pearce (2005) extends those characteristics even further. According to him the enterprises belonging to social economy sector have an over-riding social purpose - setting out to benefit people and/or the planet; they engage in trade in the open market-place - at least to some degree - but the trading is in order to achieve the social purpose; they apply profits for re-investment and community benefit, not to make individual shareholders wealthy; they hold assets in trust for the benefit of the community and future generations; they are independent of external influence and control, notably by government and by the owners of capital. It's important to add that in contemporary world the social economy business can't deny the principles of social responsibility (i.e. Pearce (2005) listed good employment practices, sound environmental practices, and principles of fair trade). In modern Europe social economy enterprises represent 2 million enterprises (i.e. $10 \%$ of all European businesses). It covers bodies with a specific legal status (cooperatives, foundations, associations, mutual societies). In the majority social economy entities are micro, small and medium sized enterprises (SMEs) independently of their business form. Social economy employs over 11 million people in the EU, accounting for $6 \%$ of total employment. $70 \%$ of these are employed in non-profit associations, $26 \%$ in cooperatives and 3\% in mutuals. Social economy enterprises are present in almost every sector of the economy, such as banking, insurance, agriculture, craft, various commercial services, and health and social services etc. It worse mention that the membership of social economy enterprises is much wider than the number of people employed and estimates ranging as high as 160 million people (The Social Economy... 2007). Terjesen et al. (2011) assessed the share of the population involved in social entrepreneurship as $4.1 \%$ in Belgium, $7.5 \%$ in Finland, 3.1\% in France, 3.3\% in Italy, 5.4\% in Slovenia and $5.7 \%$ in the United Kingdom. Approximately one in four businesses founded in Europe would therefore be a social enterprise. This figure rises to one in three in Belgium, Finland and France.

These companies are often more productive and competitive than one might think. This is due to the very high level of personal commitment on the part of their employees and the better working conditions that they provide.

\section{Social enterprises}

Social enterprises in the context of European Union policies are defined as a sub-set of the social economy (social economy operators) (The Social Economy...2012a). The research carried out in Europe revealed the diversity of the forms and activities of social enterprises. Such analytical works (Defourny and Nyssens 2008; Nyssens 2006; Borzaga and Defourny, 2001; Davister et al. 2004; Study on Practices...2007) enabled to identify the essential characteristics and operational features of any organization or company belonging to the social economy sector. The social purpose is regarded as the main trait of this kind of social-economic units. The foreign practices in social enterprise sector shows that the companies/organizations with the status of social enterprise can operate under any possible legal form or structure (Study on Practices... 2007; The Social Economy...2007; Terjesen et al. 2011). Co-operatives and non-profit organizations are the most popular forms of social enterprises in Europe. The most utilised legal forms are associations, cooperatives and foundations. The practice shows that social enterprises can be created both from zero or retrofitting existing organizations. The spectrum of activity of social enterprises is also wide. Such examples can be presented: work integration, social services, economic development, environmental protection, arts and cultural heritage, social support and human development, health, recycling, agriculture, education, nonformal vocational education and training, tourism, water economy, catering and accommodation services. Social enterprises in Europe usually deal with the problems of long-term unemployment and the issues of (re) integration into the labour market of vulnerable groups of the population. Those enterprises are basically 
small (up to 50 employees) and they operate at a local level. Most often practices while integrating vulnerable groups acting into the labour market are the provision of support services that focus on the relevant target groups (people in poverty and/or other disadvantaged groups experiencing difficulties in the labour market). Sheltered employment (the specific service intended mainly for the disabled) can be indicated as second widespread practice of integration into the labour market within social enterprises. Subsidized employment in the open labour market is also one of the most important spheres of social enterprises activities which are a part of a national/regional employment policy. In the European context, there are three main fields in which social enterprises perform their economic activity:

- $\quad$ work integration;

- $\quad$ enterprises whose primary aim is to produce goods and services with social utility or are driven by a collective interest;

- $\quad$ enterprises which foster local economic and social development (e.g., proximity services), through promoting citizen and local government participation in business running (Traveglini et al. 2010).

The first type of organizations - the work integration social enterprises (WISE) - is dominant among social enterprises. According to Davister et al. (2004) most of social enterprises appeared during the last three decades, though the work integration enterprises exist in Europe more than 50 years and aims to combat unemployment. Defourny and Nyssens (2008) notes that the main aim of social enterprises is to help lowskilled individuals who are affected by the risk of long-term unemployment or permanent dropping out of the labour market to return to employment. WISE are designed to provide such assistance through the productive activities of the organization. Sometimes for this reason social enterprise become associated with job creation initiatives only.

In the field of work integration the social enterprises often provide services for people with disabilities and for other groups of people with difficulties (re)entering labour market. Summing up the experience of European countries it is possible to define following measures for integration into the labour market: rehabilitation (vocational training, retraining and employability, etc.); anti-discriminatory laws; quota system; job subsidies; persuasion; sheltered employment; help and adaptation measures (in the workplace); business strategies for self-employed; social enterprises operate in the national schemes of employment policies and use those measures extensively. However, as was mentioned above, social enterprises also perform other tasks. For example, Defourny and Nyssens (2008) point that social enterprises assumed more responsibilities for social integration activities such as empowerment of vulnerable groups and their inclusion into work environment. It was noted that such participation gives individuals the opportunity to reevaluate the role of work in their lives and to take responsibility for their own life course. This concept envisages the productive employment of the target groups of social enterprises but also formation of values. For example the strengthening of democratic values in social enterprises can be implemented through participation in the decision-making processes; the "vaccination" of the value of collective benefits can go together with production and distribution of produced goods and services in the local community. Thus, the employment of target groups as such is not the only task for social enterprises. Defourny ir Nyssens (2008) indicated that all range of work integration social enterprises (such as community interest cooperative companies in France, social solidarity cooperatives in Portugal, social aim companies in Belgium, social initiative cooperatives in Spain, etc.) raise the provision of social services as the prime target. Alike trends are notable in other countries, for example the social firms and social cooperatives in Finland and Poland while focusing on work integration spread their activities towards social and community services. Hence the criterion of social utility (i.e., environment protection, promotion of cultural heritage and other cultural services, social tourism, research and development, education) becomes prevalent. Peattie and Morley (2008) on the basis of literature analysis (Dees 2001; Bornstein 2004; Vega and Kidwell 2007) distinguished another important feature of social enterprises: "the common perception about social enterprises that strongly rooted in the entrepreneurship tradition, is that they are inherently innovative." Although the issue of innovative nature requires sound analysis, it can't be denied that many social initiatives have the roots in the practices of social enterprises or that social enterprises are the appropriate place to test such initiatives.

As it was mentioned before, the big variety of legal and operational forms of social enterprises hampers the elaboration of single definition to describe the idea and existing practices. Nevertheless it is possible to define the key elements of such phenomena as social enterprise. The "Study on Practices and Policies in the Social Enterprise Sector in Europe" (2007) came to conclusion that in nearly all of the countries under investigation when talking about the term 'social enterprise' the following characteristics where present:

- fulfils social goals

- has a trading income

- addresses a target population in need 
- may operate under various legal forms

- deals with voluntary social work

- has a non-profit orientation or reinvests profits

- may receive public funding (Study on Practices...2007).

The European Research Network (EMES) proposes the research-based solution which today forms the central point of reference. Social enterprises can be defined as "organisations with an explicit aim to benefit the community, initiated by a group of citizens and in which the material interest of capital investors is subject to limits. They place a high value on their independence and on economic risk-taking related to ongoing socio-economic activity."

Together with definition the certain criteria for social enterprises were elaborated by EMES. It worth mention that those criteria are not strictly required, rather employed to define the ideal type of social enterprise. According to the EMES social enterprise should follow such economic and social criteria:

Economic criteria

1. Continuous activity of the production and/or sale of goods and services (rather than predominantly advisory or grant-giving functions).

2. A high level of autonomy: social enterprises are created voluntarily by groups of citizens and are managed by them, and not directly or indirectly by public authorities or private companies, even if they may benefit from grants and donations. Their shareholders have the right to participate and to leave the organisation.

3. A significant economic risk: the financial viability of social enterprises depends on the efforts of their members, who have the responsibility of ensuring adequate financial resources, unlike most public institutions.

4. Social enterprises' activities require a minimum number of paid workers, although, like traditional non-profit organisations, social enterprises may combine financial and non-financial resources, voluntary and paid work.

\section{Social criteria}

5. An explicit aim of community benefit: one of the principal aims of social enterprises is to serve the community or a specific group of people. To the same end, they also promote a sense of social responsibility at local level.

6. Citizen initiative: social enterprises are the result of collective dynamics involving people belonging to a community or to a group that shares a certain need or aim. They must maintain this dimension in one form or another.

7. Decision making not based on capital ownership: this generally means the principle of 'one member, one vote', or at least a voting power not based on capital shares. Although capital owners in social enterprises play an important role, decision-making rights are shared with other shareholders.

8. Participatory character, involving those affected by the activity: the users of social enterprises' services are represented and participate in their structures. In many cases one of the objectives is to strengthen democracy at local level through economic activity.

9. Limited distribution of profit: social enterprises include organizations that totally prohibit profit distribution as well as organizations such as co-operatives, which may distribute their profit only to a limited degree, thus avoiding profit maximizing behaviour (European Research Network 2013).

It worth mention that the distinctive features of social enterprises described above reflects the ideal model of this phenomena but the reality of social enterprise sector is much wider and still dynamic. Peattie and Morley (2008) contravened that those conventionally agreed characteristics can be used to define the social enterprises in their contemporary forms. They presented the examples of social companies that distribute profit to shareholders. Also such characteristics as small-size and democratic management, high degree of autonomy, a minimum level of paid work and a significant level of economic risk (Defourny and Nyssens 2006; Defourny 2004) are also shared by organisations that plainly are not social enterprises. In this respect Peattie and Morley (2008) represent the vantage point that the only clearly defining (rather than typical or desirable) characteristics of social enterprise can be: 1) the primacy of social aims and 2) that the primary activity involves trading goods and services.

\section{Development of social enterprises in Lithuania}

Analysis of Lithuanian enterprises was performed during the research project "The impact of labour market policies into employment situation during the different economic cycles" in 2011-2012. The evaluation of social enterprises while integrating vulnerable groups into labour market was carried out using the methods 
of document analysis, content analysis, interview of representatives of social enterprises and expert focus group. Research allowed describing major trends of development of social enterprises in Lithuania.

Lithuania as a former Soviet Union Republic has it's own traditions of work integration of disabled people through work. As a part of central planned economy cooperatives had a considerable presence in some Soviet countries. The work and vocational training enterprises for disabled people (visually impaired, deaf) that were established in late $1960^{\text {th }}$ also operated quite successfully in independent Lithuania. Those firms were among the first that got the status of social enterprises when the Law on Social Enterprises came into force in 2004 (Lithuanian Law on Social Enterprises 2004).

Lithuanian Law on Social Enterprises provides the following definition of social enterprise: Social enterprise is a legal entity of any form (individual enterprise, joint stock company, public institution) that satisfies the following conditions:

- the workers belonging to the target groups constitute no less than 40 percent of total staff and the number of such employees is not less than 4 ;

- the activities for development of professional and social skills and social integration are implemented;

- the incomes from unfunded activities of social enterprises comprise no more than 20 percent.

In 200426 companies got the status of social enterprises. Since 2004 the number of social enterprises extended to 137 in 2012. Total number of economic entities in Lithuania in 2012 was 83624; among them 17677 of small and medium-size entities (without micro-firms). Most of social enterprises are small and medium size private companies. More than half of them belong to the sector of manufacturing.

Comparing the development of Lithuanian social enterprise sector with the West European trends some similarities can be observed and described as a growth of work integration services. The employment of vulnerable groups is a key objective of social enterprises in Lithuania. The analysis of work integration mechanisms at Lithuanian social enterprises showed that in the structure of employment services for the vulnerable groups of population it can be defined as a permanent subsidized job creation for disabled people. The transitional employment and economic sustainability of the jobs as prevailed integration mechanisms defined by Davister et al. (2004) are much less noticeable in Lithuanian social enterprises.

With regard to the main characteristics of the social economy enterprises (contribution to more effective competition, primary purpose is not to obtain a return on capital, principles of solidarity and mutuality; flexible and social innovations; active membership) the national social enterprises can be defined in this way:

- The evidences from the research do not allow making the conclusion that social enterprises in Lithuania contribute to a more efficient market competition. First, the number of the social enterprises and the fields of their activities do minor changes in the structure of local economy. Second, the form of state support they receive in many cases raise them above competition. Moreover there is a little space for social enterprises to compete with the state and municipal institutions and organizations in the field of social and community services as the share of private and non-governmental providers is minor.

- In general Lithuanian social enterprises reinvest the profit to the needs of enterprise, although part of the enterprises with low productivity doesn't gain profit or gain minor profit so the question of return on capital is not relevant for them.

- With little exceptions there is no mechanism entrenched for accountable of social enterprises to those they are meant to serve. Only social enterprises operating in close collaboration with NGO's representing disabled people do such practice.

- The principles of democratic management are also neglected quite often. This is typical for the social enterprises that didn't join any of three associative organizations for such enterprises.

- Clear orientation to work integration activities and quite narrow range of vocational activities to offer for disadvantaged groups suggest that the total level of innovative ones is low among Lithuanian social enterprises. Though some outstanding examples such as social enterprises providing research activities or tele-marketing can be listed.

- It should be mentioned that only few social enterprises provide social services for the members of local communities, while the proportions of the enterprises seeking for fulfilment of the needs of particular groups of society (i.e. disabled, elderly people, lonely parents, migrant communities, etc.) or to improve the conditions within local community is bigger, though not sufficient yet.

- Another distinctive feature of Lithuanian social enterprises is absence of voluntary work. The main reasons are the lack of traditions and the poor legislative basis for voluntary work, as well as reticence of the social enterprises. 


\section{Conclusions}

Social enterprises in our country occupy a specific place among other social and employment policy measures. The complete evaluation of the performance of these enterprises is not possible without deep perception of national social and economic context. The analysis performed during the research prompts an assumption that national social enterprises as an important part of the development of national social policy sets Lithuanian social policy framework closer to liberal model welfare state.

The Lithuanian social enterprise sector in the context of Western Europe acquires slightly different shape and content. The work integration social enterprises are dominant both in Lithuania and in other EU countries. The rule of limited distribution of profit is established in the national Law of Social Enterprises. The employees belonging to target groups usually receive minimum wage. However the participation of the Lithuanian social enterprises in the provision of social and community services is much lower than in Western European countries. It was also defined that social enterprises serve the community or a specific group of people. In the case of Lithuania the key beneficiary group is disabled people, while the other vulnerable groups and the needs of local communities are not in the focus of social enterprises activities yet. The demand for the social enterprises in Lithuania is expected to rise. The structure of the national labour market and quite low level of its inclusiveness cause the need for work integration services in the country. The number of social enterprises that produce goods and services with social utility or are driven by a collective interest is also supposed to rise.

\section{References}

Annual Growth Survey. 2011. Communication from the Commission. COM(2011) 815 final. Vol. 1/5. Brussels, 23.11.2011.

Bornstein, D. 2004. How to Change the World: Social Entrepreneurs and the Power of New Ideas. Oxford University Press, Oxford.

Borzaga, C.; Defourny, J. 2001. The emergence of Social Enterprise. Routledge, London.

Browne, P. L. 1997. The two faces of the social economy. Paper presented at the Eighth Conference of Canadian Welfare Policy, University of Regina, Saskatchewan.

Davister, C.; Deforny, J.; Grégoire, O. 2004. Work Integration Social Enterprises in the European Union an Overview of Existing Models, Working Paper Series, 04/04, Liège: EMES European Research Network.

De la Fuente, A. 2010. Fewer people outside the labour force in 2009. Statistics in focus. 57/2010. Population and social conditions. Available on the Internet: 〈http://epp.eurostat.ec.europa.eu/cache/ITY_OFFPUB/KS-SF-10-057/EN/KS-SF-10-057-EN.PDF>.

Dees, J.G. 2001. The Meaning of Social Enterprise, Stanford University, Palo Alto, CA.

Defourny, J.; Nyssens, M. 2008. Social Enterprise in Europe: Recent Trends and Developments, Social Enterprise Journal 4(3): 202228.

Defourny, J. 2004. From third sector to social enterprise, in Borzaga, C.; Defourny, J. (Eds.). The Emergence of Social Enterprise. Routledge, London.

Defourny, J.; Nyssens, M. 2006. Defining social enterprise, in Nyssens, M. (Eds.). Social Enterprise - At the Crossroads of Market, Public and Civil Society. Routledge, London.

Dupre, D.; Karjalainen, A. 2003. Employment of disabled people in Europe in 2002. Statistics in focus. Population and social conditions. Theme $3-26 / 2003$.

Employment in Europe. 2008. Report. Brussels. Available on the Internet: <http://europa.eu/rapid/press-release_MEMO-08719_en.htm>.

Employment in Europe. 2011. European Commission. Brussels. Available on the Internet: $<$ http://ec.europa.eu/employment_social/eie/chap1-1_en.html>.

Eurostat. 2012. Key figures on Europe 2012. Luxembourg: Publications Office of the European Union. Available on the Internet: <http://epp.eurostat.ec.europa.eu/cache/ITY_OFFPUB/KS-EI-12-001/EN/KS-EI-12-001-EN.PDF>.

Europe 2020 targets: Poverty and Social Exclusion. Active Inclusion Strategies. 2012. Available on the Internet: <http://ec.europa.eu/europe2020/pdf/themes/25_poverty_and_social_inclusion.pdf >.

European Commission. 2012. Available on the Internet: <http://ec.europa.eu/enterprise/policies/sme/promoting- 
entrepreneurship/social-economy/>.

European Council, Presidency Conclusions, Nice European Council Meeting. 2000. Annex 1, European Social Agenda, § 11.

European Research Network. 2013. Available on the Internet: <http://www.emes.net/index.php?id=203>.

Eurostat news release. 2012. 171/2012-3 December 2012 . Available on the Internet: <http://epp.eurostat.ec.europa.eu/cache/ITY_PUBLIC/3-03122012-AP/EN/3-03122012-AP-EN.PDF>.

Freysson, L. 2012. General government expenditure: Analysis by detailed economic function. Statistics in focus. 33/2012. Economy and finance. Available on the Internet: <http://epp.eurostat.ec.europa.eu/cache/ITY_OFFPUB/KS-SF-12-033/EN/KS-SF-12-033EN.PDF>.

Index of economic forecasts. 2010. Interim economic forecast of September 2010. European Commission. Available on the Internet: <http://ec.europa.eu/economy_finance/publications/european_economy/forecasts_en.htm>.

Lithuanian Law on Social Enterprises. 2004. Official Gazette, No. 96-3519.

Monzon,J.L. 1989. Las cooperativas de trabajo asociado en la literatura economica y en los hechos, Ministerio de Trabajo y Seguridad Social, Madrid.

Moulaert, F.; Ailenei, O. 2005. Social Economy, Third Sector and Solidarity Relations: A Conceptual Synthesis from History to Present. Urban studies. 2005 42: 2037. Available on the Internet: <http://usj.sagepub.com/content/42/11/2037.full.pdf+html〉.

Nyssens, M. 2006. Social Enterprise. At the crossroads of market, public policies and civil society. Routledge, Londres and New York.

Pearce, J. 2005. The Future of Social Enterprise. A speech to launch Wiselink on 6th December 2005. Available on the Internet: <http://www.senscot.net/view_res.php?viewid=3989>.

Pearce, J. 2003. Social Enterprise in Anytown. Calouste Gulbenkian Foundation.

Peattie, K.; Morley, A. 2008. Eight paradoxes of the social enterprise research agenda, Social Enterprise Journal 4(2): 91-107.

Study on Practices and Policies in the Social Enterprise Sector in Europe. 2007. Final Report. Austrian Institute for SME Research and TSE Entre, Turku School of Economics. Vienna. Available on the Internet: $<$ http://ec.europa.eu/enterprise/newsroom/cf/_getdocument.cfm?doc_id=3408>.

Terjesen, S.; Lepoutre, J.; Justo, R.; Bosma, N. 2011. Global Entrepreneurship Monitor Report on Social Entrepreneurship. Available on the Internet: 〈http://www.gemconsortium.org/about.aspx?page=pub_gem_special_topic_reports〉.

The Social economy in the European Union. 2007. Report N ${ }^{\circ}$. CESE/COMM/05/2005 for the European Economic and Social Committee (EESC). International Centre of Research and Information on the Public, Social and Cooperative Economy (CIRIEC).

The Social Economy in the European Union. 2012a. Austrian Institute for SME Research and TSE Entre, Turku School of Economics. Vienna.

The Social Economy in the European Union. 2012b. Summary of the Report drawn up for the European

Economic and Social Committee by the International Centre of Research and Information on the Public, Social and Cooperative Economy (CIRIEC). Available on the Internet: 〈http://www.eesc.europa.eu/resources/docs/qe-31-12-784-en-c.pdf〉.

Traveglini, C.; Bandini, F.; Mancione, K. 2010. Social Enterprise in Europe: Governance Models. An analysis of governance models in social enterprises through a comparative study of the legislation of eleven countries. AICCON Working Papers. 75-2010, Associazione Italiana per la Cultura della Cooperazione $\mathrm{e}$ del Non Profit. Available on the Internet: <http://www.aiccon.it/file/convdoc/wp75.pdf>.

Vega, G.; Kidwell, R.E. 2007. Toward a typology of new venture creators: similarities and contrasts between business and social entrepreneurs, New England Journal of Entrepreneurship 10(2): 15-28. 